\title{
Physical Education Learning Model Base on Information, Communication Technology
}

\author{
H. Widyaningsih \\ Universitas Negeri Jakarta, Indonesia \\ Eva Yulianti \\ Universitas Negeri Jakarta, Indonesia \\ Iwan Setiawan \\ Universitas Negeri Jakarta, Indonesia
}

\begin{abstract}
There was a revolution in the learning process in schools during the COVID-19 pandemic. At this time, the digital era plays a very important role in replacing human interaction in carrying out all life activities in almost all fields. Currently the teaching and learning process is carried out online. However, for the field of motion learning in physical education, students still have to be able to practice the sports movements that have been arranged in the curriculum. This study aims to determine what learning models are used in providing motion learning materials during this pandemic. Methods: This study used is a survey method with descriptive analysis. The sample in this study were physical education teachers in Junior High Schools in Jakarta. Results: This study showed that the online physical education learning model that is most widely mastered and used in the teaching and learning process. Conclusion: The most widely used media in learning physical education are live youtube and motion learning videos.
\end{abstract}

Keywords---communication technology, information, learning base online, learning model, physical education.

\section{Introduction}

Teacher quality is an important determinant of student outcomes (Kin, 2021; Zulkifli \& Danis, 2021). Learning in sports education which is carried out in the field or outside the classroom, can now be done in the classroom without reducing the composition of sports and physical education learning materials (MacWhinney \& Leinbach, 1991). Physical education teachers can improve

Linguistics and Culture Review (c) 2021.

Corresponding author: Widyaningsih, H.; Email: heniwidyaningsih@unj.ac.id

Manuscript submitted: 18 July 2021, Manuscript revised: 09 Oct 202 1, Accepted for publication: 27 Nov 2021 
personal competence in the field of learning by using ICT-based learning media. Of course this can increase the competence of physical education teachers which will improve other competencies such as pedagogical competence, social competence and professional competence.

But currently in Indonesia and also in many countries experiencing a pandemic with the spread of the Corona-19 (COVID-19) virus outbreak, the spread and transmission of which is very active and fast through human interactions. Because of this, the government, especially the DKI Jakarta Government issued a regulation to implement large scale social restriction for a fairly long period of time. This regulation makes teaching and learning less disturbed due to the implementation of physical improvements (physical distance) in the school environment from various levels from early childhood education to college. However, the learning process must be carried out even in conditions that must be separated from the learning room at school.

Teachers and teachers are looking for ways to make learning materials acceptable to students in accordance with the applicable curriculum. With information media, communication and technology in the end become an option as a learning tool that can reach long distances (Sher \& Lee, 2004). Methods in the network (online) as a means of distance learning which is ultimately an option in the learning process. There are many learning methods that can accommodate the distance learning process (online), especially in theoretical and practical subjects such as Whatapps Group, Google Classroom, Edmodo, G Suite, Moodle, Youtube Channel and so on. However, with the advantages of the distance learning method, there are limitations to physical education learning (Hassandra et al., 2003; Haerens et al., 2015). Physical education learning must be measured from the movements performed by students because in Physical Education learning there needs to be a demonstration of measurable sports movements. Physical education teachers often take teaching materials from YouTube channels or make their own teaching videos which are then submitted to students via the internet or other communication media (Shachaf, 2008; Pratt et al., 2012). Unfortunately, the video given to students is still limited in duration because it is related to the quota and network for these students. In addition, there are still many Physical Education teachers who do not master online learning tools because of various age factors and also their understanding of the latest technology (Song et al., 2004).

Looking at this fact, it is necessary to have physical education learning facilities that can be run while still implementing the curriculum achievement targets (Kalynychenko et al., 2021). The means that allow for Physical Education learning in such conditions is to use the means of Information, Communication and Technology (ICT) (Mun et al., 2006). This ICT-based learning media is physical education learning through 3-dimensional videos that can capture perspectives from various points of view at relatively low prices and reach. In addition, students can also see clearly and carefully all good and correct postures and sports movements (Manrique, 2021).

Currently developing applications that can see a clear and real picture of an illustration or image. This illustration can be seen in 2 dimensions or 3 
dimensions which are combined into a real environment then with the help of an application that can project these virtual objects into a reality. This application is Augmented Reality (AR). AR is quite popular in the marketing and medical world as a medium of promotion and learning, but actually it can also be applied as a physical education learning medium.

Physical education learning media using the AR application can also help students with disabilities or students with special needs (inclusion) to get the same teaching material as other students (Ginaya et al., 2020). Physical education learning materials using the AR application will make it easier for Physical Education teachers to provide learning material, increase professionalism, add pedagogical and social insights. Meanwhile, students will receive the rights they should have if the weather conditions are not conducive. But the question is whether physical education teachers have the understanding and knowledge of using AR applications as an option in distance learning methods. Based on this, in this study a map of the ability of physical education teachers to master distance learning methods by utilizing information, communication and technology media including Augmented Reality (AR) will be made (Suryasa et al., 2019).

\section{Materials and Methods Materials}

Teacher education is inherent in adults who are able to convey intellectual and motor skills and knowledge to younger people, called pupils or students. Teachers are often role models for students both morally and informally outside of school. Likewise, as a physical education teacher, in a lesson, the process of planning behavior change in students. Likewise with Physical Education teachers, every teaching material has the goal of creating student change, especially in coordinated physical activity in sports movements. Sports learning can be improved through new existing ones by demonstrating or demonstrating good sports movements that are tailored to the character of students (Rönnqvist et al., 2019).

Movement skills in physical education learning in schools aim to help students develop movement skills towards certain performance. Learning motion is a study of the process in skills skills, and the variables that support or hinder learning (Widiastuti, 2015). In Physical Education learning at the Elementary School level the main goal is not achievement in a particular sport, but lies in the development and growth of physical, mental, social harmony in the basic movement menu, instilling values, attitudes and getting used to a healthy lifestyle. Physical education learning at higher level schools provides a larger portion of practicum so that for the middle school level there are branch sports practices outside of school hours with the aim of getting superior seeds for sports athletes who will receive further guidance. Thus, it is necessary to have variations and modifications to the sports learning model based on championships by physical education teachers at the secondary school level (Dalton \& Rachman, 2014; Marzouket al., 2021). 
A physical education teacher must have good sports movement skills, so that they are able to demonstrate sports movements that become learning material (Lukman et al., 2016). Through demonstrations of the movement of sports that are conveyed correctly by the physical education teacher, it will be easier for students to understand the material presented (Rönnqvist et al., 2019). Learning sports movements can be improved through existing guidelines by showing or demonstrating good sports movements that are tailored to the character of students so that students can understand what is being learned, opportunities to respond, the ability for feedback and the reinforcement of learning material (Widyaningsih et al., 2019).

However, if the physical education learning that the teacher should be present in front of the students then demonstrates sports movements during a pandemic like now it is definitely impossible to do. Because of this, Physical Education learning must use other learning methods using technology assistance that is broad and easy to access by all students at home. There is an application that is currently widely used in marketing and other fields that can present a virtual world like the real world that can be seen in 3 Dimensions (3D), namely Augmented Reality (AR).

By introducing AR, teachers can prepare a way of learning that can break the boundaries of traditional learning. Learning development is prepared by designing learning with AR where students have the opportunity to understand the concept of education from their own understanding (Chen \& Geng, 2001). By introducing $\mathrm{AR}$, can help teachers explain teaching materials by combining the ability to communicate and skills from 2 teaching materials (biology and geography) so that lessons become more interesting (Iftene \& Trandabăt, 2018).

In the end, teachers are forced to play an active role in the use of technology where this technology is an innovative solution in closing the education gap in a pandemic like this (Chick et al., 2020). Currently, the use of AR in physical education learning materials is still not popular even though AR can be applied in almost all fields including education. The biggest obstacle is that the AR application has not been socialized to users, namely Physical Education teachers and students. AR will support in all fields such as education and also acceptance in other fields (Van \& Poelman, 2010).

\section{Methods}

The methodology used in this study is a survey method, namely the data collection technique by distributing questionnaires containing questions and statements in accordance with the research indicators to respondents, namely physical education teachers in the Jakarta area. The number of answered questionnaires was 28 people which were then analyzed and then presented descriptively as the results of the study.

\section{Result and Discussion}

Learning media is an intermediary tool between educators and students in learning that is able to connect, provide information and channel messages so 
that an effective and efficient learning process is created. Through this research, it will be known how much understanding the Physical Education teacher in carrying out distance learning by utilizing information systems, communication and technology. The data that was successfully summarized from the results of the distribution of the questionnaire were collected then grouped based on the criteria after which it was analyzed and finally described descriptively.

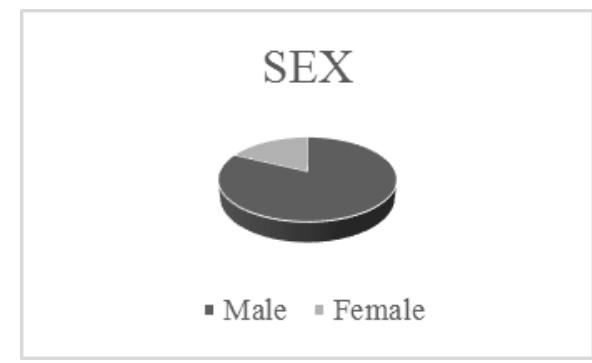

Figure. 1 Distribution of gender of all respondents

Of the 28 respondents who filled out the questionnaire completely, 5 were female and 23 male teachers. This right shows that almost $18 \%$ of female respondents were represented while male respondents were $82 \%$ more (Figure. 1).

In fact, the majority of physical education teachers are male. In Jakarta in particular and in Indonesia in general, physical education teachers are mostly male, but the number of female physical education teachers continues to increase from year to year. Male and female teachers have their respective strengths and weaknesses. The performance of female Physical Education teachers has a higher level of performance than male Physical Education teachers in terms of learning preparation, learning opening. However, for the problem of class management, material delivery and class closure, there were no significant differences (Kawehilani, 2011).

The age distribution of the 28 respondents who returned the questionnaire varied widely, with the youngest being under 30 years old to 60 years old or nearing retirement. Most modes or ages in this study were in the range of $40-49$ years (Figure. 2).

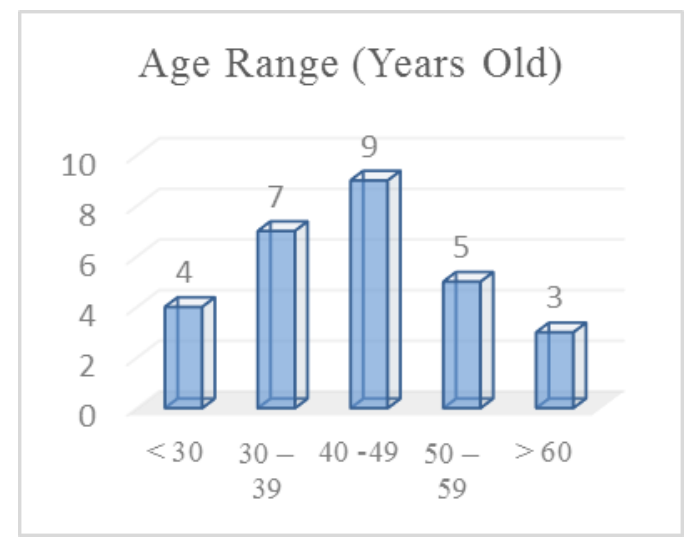

Figure 2. Age distribution of respondents 
Based on Government Regulation No. 19 of 2017 concerning Amendments to Government Regulation No. 74 of 2008 concerning Teachers (Government Regulation, 2017), Article 15 point 4 states that the professional allowance will be given until the age of 60 . So it can be explained that the respondents who are approaching retirement age are more than $10 \%$. Based on the Manpower Act number 13 of 2003, the age limit for workers is between 13 - 65 years. This means that a person is still able to do work up to the age of 65 .

Based on the learning media used by Physical Education teachers are very diverse. There are some teachers who use more than 1 learning media online (Hagras et al., 2003). This is done to cover the weaknesses of one media with another. For example, there is a physical education teacher who provides material to students through the WhatApps Group in the form of learning videos taken from the existing Youtube Channel. By looking at the following table, it can be explained that most Physical Education teachers in carrying out their duties as teachers by using the Youtube Channel and the Zoom Meeting Application respectively $23.7 \%$. Meanwhile, those who used Google Classroom were $21.2 \%$ and WhatApps Group were $15.3 \%$ (Table 1).

Table 1

Online learning media

\begin{tabular}{clcc}
\hline No & Learning Media & Total & $\begin{array}{c}\text { Persentase } \\
(\%)\end{array}$ \\
\hline 1 & WAG & 18 & 15.3 \\
2 & Youtube & 28 & 23.7 \\
3 & GCR & 25 & 21.2 \\
4 & Zoom & 28 & 23.7 \\
5 & Moodle & 12 & 10.2 \\
6 & LMS & 0 & 0 \\
7 & Edmudo & 0 & 0 \\
8 & G Suite & 2 & 1.6 \\
9 & Lainnya & 5 & 4.3 \\
& Total & 118 & 100 \\
\hline
\end{tabular}

Based on mastery of the use of instructional media using online distance learning and the result is that all teachers understand how to operate the WhatApps Group. Physical education teachers by $78 \%$ master the use of zoom meeting and downloading videos via youtub channel. The rest of the physical education teacher mastery with Google Classroom and Moodle is only $68 \%$ and $28 \%$ (Table 2).

Table 2

Mastery of physical education teachers in online learning media

\begin{tabular}{lcccc}
\hline Learning Media & Control & Less Mastery & $\begin{array}{c}\text { Not } \\
\text { Mastering }\end{array}$ & Mastery Level \\
\hline WAG & 28 & 0 & 0 & 100 \\
Youtube & 22 & 6 & 0 & 78
\end{tabular}




\begin{tabular}{lcccc} 
GCR & 19 & 4 & 2 & 68 \\
Zoom & 22 & 5 & 1 & 78 \\
Moodle & 8 & 4 & 16 & 28 \\
\hline
\end{tabular}

Conclusion

Learning in sports education that is carried out in the field or outside the classroom, can now be done in the classroom without reducing the composition of sports and physical education learning materials. Physical education teachers can improve personal competence in the field of learning by using ICT-based learning media. There are many online learning media that can be accessed by teachers including: what'sapp, blog, zoom, webex, google meet, google classroom, messengger, instagram live, youtube live, G suite, moodle, edmudo, Learning Management System and other application based media. However, the most widely used media in learning physical education are live youtube and motion learning videos.

\section{Acknowledgement}

This research was funded by POK BLU FIO UNJ in 2020. research and community service are mandatory activities for lecturers besides teaching to fulfill the Tri Dharma of Higher Education. This research is routinely granted to all lecturers at the Faculty of Sports Science, State University of Jakarta who are competitive with certain requirements.

\section{References}

Chen, C. H., \& Geng, C. Q. (2001). Exclusive decays of $\mathrm{B} \rightarrow \mathrm{K}\left({ }^{*}\right) 1+1-$ in perturbative QCD. Physical Review D, 63(11), 114025.

Chick, R. C., Clifton, G. T., Peace, K. M., Propper, B. W., Hale, D. F., Alseidi, A. A., \& Vreeland, T. J. (2020). Using technology to maintain the education of residents during the COVID-19 pandemic. Journal of surgical education, 77(4), 729-732. https://doi.org/10.1016/j.jsurg.2020.03.018

Dalton, W., \& Rachman, H. A. (2014). Modifikasi Model Pembelajaran Sport Education Berbasis Kejuaraan Untuk Guru Penjas SMP. Jurnal keolahragaan, 2(1), 106-118.

Ginaya, G., Kanca, I. N., \& Sri Astuti, N. N. (2020). Designing problem-based learning (PBL) model for tourism vocational education in 4.0 industry. International Journal of Linguistics, Literature and Culture, 6(1), 1423. https://doi.org/10.21744/ijllc.v6n1.808

Haerens, L., Aelterman, N., Vansteenkiste, M., Soenens, B., \& Van Petegem, S. (2015). Do perceived autonomy-supportive and controlling teaching relate to physical education students' motivational experiences through unique pathways? Distinguishing between the bright and dark side of motivation. Psychology of sport and exercise, 16, 26-36. https://doi.org/10.1016/j.psychsport.2014.08.013

Hagras, H., Callaghan, V., Colley, M., \& Clarke, G. (2003). A hierarchical fuzzygenetic multi-agent architecture for intelligent buildings online learning, adaptation and control. Information Sciences, 150(1-2), 33-57. https:/ / doi.org/10.1016/S0020-0255(02)00368-7 
Hassandra, M., Goudas, M., \& Chroni, S. (2003). Examining factors associated with intrinsic motivation in physical education: a qualitative approach. Psychology of sport and exercise, 4(3), 211-223. https:/ /doi.org/10.1016/S1469-0292(02)00006-7

Iftene, A., \& Trandabăț, D. (2018). Enhancing the attractiveness of learning through augmented reality. Procedia Computer Science, 126, 166-175. https://doi.org/10.1016/j.procs.2018.07.220

Kalynychenko, I. A., Latina, H. O., Kopytina, Y. M., Protsenko, I. I., \& Ivanii, I. V. (2021). Formation of professional-pedagogical culture of future specialists of physical culture and sports specialties. Linguistics and Culture Review, 5(S3), 396-410. https://doi.org/10.21744/lingcure.v5nS3.1540

Kawehilani, R. S. (2011). Perbedaan kualitas pengajaran antara guru laki-laki dan perempuan dalam pembelajaran penjasorkes di Kabupaten Brebes tahun pelajaran 2010/2011 (Doctoral dissertation, Universitas Negeri Semarang (UNNES)).

Kin, M. (2021). An Analysis on the Implementation of Professional Learning Communities in Malaysian Secondary Schools. Asian Journal of University Education, 17(1), 192-206.

Lukman, .-., Abdulhak, I., \& Wahyudin, D. (2016). Learning model development to improve students' oral communication skill: (a research and development study on english as a foreign language (EFL) subject in all junior high schools in north of lombok, west nusa tenggara province). International Journal of Linguistics, Literature and Culture, 2(2), 147-166.

MacWhinney, B., \& Leinbach, J. (1991). Implementations are not conceptualizations: Revising the verb learning model. Cognition, 40(1-2), 121157. https://doi.org/10.1016/0010-0277(91)90048-9

Manrique, I. L.-. (2021). Art education and sensitive tolos innovation project in the training of early childhood education teachers. Linguistics and Culture Review, 5(S3), 794-805. https://doi.org/10.21744/lingcure.v5nS3.1728

Marzouk, M., Elshaboury, N., Abdel-Latif, A., \& Azab, S. (2021). Deep learning model for forecasting COVID-19 outbreak in Egypt. Process Safety and Environmental Protection, 153, 363-375. https://doi.org/10.1016/j.psep.2021.07.034

Mun, Y. Y., Jackson, J. D., Park, J. S., \& Probst, J. C. (2006). Understanding information technology acceptance by individual professionals: Toward an integrative view. Information \& Management, 43(3), 350-363. https://doi.org/10.1016/j.im.2005.08.006

Pratt, M., Sarmiento, O. L., Montes, F., Ogilvie, D., Marcus, B. H., Perez, L. G., ... \& Lancet Physical Activity Series Working Group. (2012). The implications of megatrends in information and communication technology and transportation for changes in global physical activity. The Lancet, 380(9838), 282-293. https://doi.org/10.1016/S0140-6736(12)60736-3

Rönnqvist, M., Larsson, H., Nyberg, G., \& Barker, D. (2019). Understanding learners' sense making of movement learning in physical education. Curriculum Studies in Health and Physical Education, 10(2), 172-186.

Shachaf, P. (2008). Cultural diversity and information and communication technology impacts on global virtual teams: An exploratory study. Information \& Management, 45(2), 131-142. https://doi.org/10.1016/j.im.2007.12.003 
Sher, P. J., \& Lee, V. C. (2004). Information technology as a facilitator for enhancing dynamic capabilities through knowledge management. Information \& management, 41(8), 933-945. https://doi.org/10.1016/j.im.2003.06.004

Song, L., Singleton, E. S., Hill, J. R., \& Koh, M. H. (2004). Improving online learning: Student perceptions of useful and challenging characteristics. The internet and higher education, 7(1), 59-70. https://doi.org/10.1016/j.iheduc.2003.11.003

Suryasa, I.W., Sudipa, I.N., Puspani, I.A.M., Netra, I.M. (2019). Translation procedure of happy emotion of english into indonesian in kṛ̦na text. Journal of Language Teaching and Research, 10(4), 738-746

Van Krevelen, D. W. F., \& Poelman, R. (2010). A survey of augmented reality technologies, applications and limitations. International journal of virtual reality, 9(2), 1-20.

Widiastuti. (2015). Tes dan pengukuran olahraga. Jakarta: PT Raja Grafindo Persada.

Widyaningsih, H., Asmawi, A., \& Tangkudung, J. A. (2019). The implementation of physical education learning based on local excellence. In Journal of Physics: Conference Series (Vol. 1318, No. 1, p. 012113). IOP Publishing.

Zulkifli, A. F., \& Danis, A. (2021). Exploration of CoachEye application features to improve feedback during physical education. Asian Journal of University Education (AJUE), 7(2), 132-143. 